\title{
The effect of addition of yellow lupin seeds (Lupinus luteus L.) to laying hen diets on performance and egg quality parameters
}

\author{
A. Rutkowski ${ }^{1}$, M. Hejdysz ${ }^{1,5}$, S. Kaczmarek ${ }^{1}$, M. Adamski ${ }^{3}$, S. Nowaczewski ${ }^{2}$ and D. Jamroz ${ }^{4}$ \\ Poznań University of Life Sciences \\ 1 Department of Animal Nutrition and Feed Management, Wołyńska 33, 60-637 Poznań, Poland \\ ${ }^{2}$ Department of Animal Breeding and Product Quality Assessment, Złotniki, Słoneczna 1, 62-002 Suchy Las, Poland \\ ${ }^{3}$ University of Technology and Life Sciences in Bydgoszcz, Department of Poultry Breeding \\ Mazowiecka 28, 85-084 Bydgoszcz, Poland \\ ${ }^{4}$ Wrocław University of Environmental and Life Sciences, Department of Animal Nutrition and Feed Quality \\ Chełmońskiego 38C, 51-630 Wrocław, Poland
}

KEY WORDS: Lupinus luteus, seeds, hens, performance, egg quality

Received: 6 February 2017

Revised: 22 June 2017

Accepted: 31 August 2017

${ }^{5}$ Corresponding author:

e-mail: marhej@up.poznan.pl

\begin{abstract}
The aim of the present study was to determine the influence of a new variety of yellow lupin (Lupinus luteus L.) var. Mister seeds in laying hens diet on their performance and egg quality parameters. The experiment was performed on 17-week old $360 \mathrm{Hy}$-Line Brown hens housed in cages. Hens were randomly assigned to five treatments, each with 24 replications. Starting from 21 week of age birds were fed five different diets: control (without lupin seeds) and with 10,15, 20 and 25\% inclusion of yellow lupin seeds. Dietary inclusion of $25 \%$ lupin seeds significantly decreased the mean laying rate and egg weight. Also, the lowest dietary consumption and the worst feed conversion ratio were found in birds fed diet with $25 \%$ lupin seeds addition; the best results were found in the control animals. As the yellow lupin seeds content in the diets increased, the $\mathrm{pH}$ value of yolk and albumen increased, also Haugh unit scores and yolk pigmentation were significantly higher but shell thickness and strength was decreased. So, the inclusion of up to $20 \%$ yellow lupin seeds into diet did not decrease laying rate and egg weight. In line with the increasing lupin content in diets the egg quality was deteriorated (except for yolk pigmentation).
\end{abstract}

\section{Introduction}

Soyabean meal (SBM) is the main vegetable protein source in poultry diet. However, in countries that are not climatically adapted to soyabean production the inclusion of home-grown legume seeds into diets for non-ruminant animals as an alternative to soyabean products has been receiving attention (Laudadio and Tufarelli, 2011b; Kaczmarek et al., 2015; Rutkowski et al., 2015; Hejdysz et al., 2016, 2017; Kasprowicz-Potocka et al., 2016). In the past, the use of yellow lupin as a source of protein for poultry was limited due to its high alkaloid, nonstarch polysaccharides (NSP) and other anti-nutrients contents that negatively affected the bird performance (Gdala and Buraczewska, 1996; Knudsen, 1997; Gdala, 1998; Wasilewko and Buraczewska, 1999; Jamroz and Kubizna, 2008; Laudadio and Tufarelli, 2011a). However, in the last decades, plant breeders have succeeded in developing lupin cultivars characterized by a very low alkaloid content. The NSP level in lupin is almost twice as high as in 
other protein-rich plants (Gdala and Buraczewska, 1996; Knudsen, 1997, 2014) and is still a nutritional problem. These authors claimed that the soluble NSP content in some old Polish cultivars of yellow lupin seeds ranged from 2.0 to over $12.0 \%$. Yet, according to later research, lupin protein is digested to the same degree as from SBM (Hughes and Kocher 1998; Hammershoj and Steenfeldt, 2005) or even better (Kaczmarek et al., 2014, 2015).

The effect of raw materials on yolk colour is a well-known phenomenon: maize contains lutein and zeaxanthin at concentrations of 20 to $25 \mathrm{mg}$ of xanthophyll $\cdot \mathrm{kg}^{-1}$, carrot meal contains 54 to $65 \mathrm{mg}$ of xanthophyll $\cdot \mathrm{kg}^{-1}$ (Sikder et al., 1998; Dvořák et al., 2007). Maize silage (grains and cobs) exert a positive effect on yolk colour when included in diets for laying hens.

Therefore, the aim of the present study was to determine the influence of a new variety of yellow lupin seeds (var. Mister) added into laying hen diets on their performance and egg quality parameters.

\section{Material and methods}

\section{Animals and diets}

The study was conducted accordingly to the guidelines of the Local Ethics Commission with respect to animal experimentation and care of animals under study.

In total, 360 17-week old Hy-Line Brown hens were weighed and randomly allocated into cages (3 birds in each cage) with ad libitum access to drinking water and feed. Animals were fed pre-laying feed mixture containing $14.5 \%$ of crude protein and $11 \mathrm{MJ} \cdot \mathrm{kg}^{-1}$ metabolizable energy from the 17 to 21 week of age. Before the beginning of egg production, birds were randomly assigned to five treatments, 24 replicates in each. The experiment started at the 21 week of age. Birds from the control group were fed a diet based on wheat/native grain in which soyabean meal and rapeseed meal were the main protein sources. Experimental diets consisted of a constant content of peas var. Trachalska (10\%); soyabean meal and rapeseed meal were replaced with yellow lupin seeds var. Mister (Table 1) in the amounts of 10, 15, 20 and 25\% (Table 2). Animals had free access to water, and isonitrogenous and isoenergetic diets in a mash form. The $14 \mathrm{~h} \mathrm{light} / 10 \mathrm{~h}$ dark cycle was provided. The chemical composition of diets (Table 2) was calculated using linear optimalization on the basis of our own chemical analysis of the used components.
Table 1. Chemical composition of yellow lupin seeds var. Mister

\begin{tabular}{|c|c|}
\hline Indices & Content \\
\hline Dry matter, $\mathrm{g} \cdot \mathrm{kg}^{-1}$ seeds & 890.1 \\
\hline \multicolumn{2}{|l|}{$\mathrm{g} \cdot \mathrm{kg}^{-1} \mathrm{DM}$} \\
\hline crude ash & 41.5 \\
\hline crude protein & 389.8 \\
\hline crude fibre & 192.3 \\
\hline ADF & 242.4 \\
\hline NDF & 282.4 \\
\hline crude fat & 52.6 \\
\hline carotenes & 2.3 \\
\hline xanthophylls & 13.6 \\
\hline Gross energy, $\mathrm{MJ} \cdot \mathrm{kg}^{-1}$ & 20.49 \\
\hline Viscosity, $\mathrm{cP}$ & 1.09 \\
\hline \multicolumn{2}{|l|}{ Amino acid, g amino acid/16 g N } \\
\hline Asp & 8.81 \\
\hline Glu & 24.46 \\
\hline Ala & 2.83 \\
\hline Cys & 2.56 \\
\hline Gly & 3.47 \\
\hline lle & 3.20 \\
\hline Leu & 6.50 \\
\hline Met & 0.81 \\
\hline Phe & 4.24 \\
\hline Pro & 6.08 \\
\hline Ser & 4.24 \\
\hline Thr & 3.17 \\
\hline Tyr & 3.24 \\
\hline Val & 3.17 \\
\hline $\operatorname{Arg}$ & 10.12 \\
\hline Lys & 4.76 \\
\hline His & 3.32 \\
\hline \multicolumn{2}{|l|}{ Antinutrients } \\
\hline total alkaloids, $\mathrm{g} \cdot \mathrm{kg}^{-1} \mathrm{DM}$ & 0.027 \\
\hline lupinine, in total alkaloids, \% & 63.29 \\
\hline sparteine, in total alkaloids, $\%$ & 33.6 \\
\hline ammodendrine, in total alkaloids, $\%$ & 3.12 \\
\hline oligosaccharides, $\mathrm{g} \cdot \mathrm{kg}^{-1} \mathrm{DM}$ & 8.57 \\
\hline rafinose, $\mathrm{g} \cdot \mathrm{kg}^{-1} \mathrm{DM}$ & 1.10 \\
\hline stachyose, $\mathrm{g} \cdot \mathrm{kg}^{-1} \mathrm{DM}$ & 4.94 \\
\hline verbascose, $\mathrm{g} \cdot \mathrm{kg}^{-1} \mathrm{DM}$ & 2.53 \\
\hline P-phytate, $\mathrm{g} \cdot \mathrm{kg}^{-1} \mathrm{DM}$ & 7.0 \\
\hline P-phytate/P total, \% & 75.0 \\
\hline
\end{tabular}

\section{Collected data}

In the study the following parameters were examined:

- initial and final body weight of hens (for each replicate),

- week feed intake and feed conversion ratio (FCR) (for each replicate),

- $\quad$ egg weight with $0.1 \mathrm{~g}$ accuracy (g), determined weekly for 20 eggs from each replicate,

- $\quad$ egg shape index (ESI, \%) calculated according to the formula:

$\mathrm{ESI}=$ egg width $(\mathrm{mm}) \times 100 /$ egg height $(\mathrm{mm})$, 
Table 2. Composition of experimental diets

\begin{tabular}{|c|c|c|c|c|c|}
\hline \multirow{3}{*}{ Indices } & \multicolumn{5}{|c|}{ Treatments } \\
\hline & \multirow{2}{*}{ control } & \multicolumn{4}{|c|}{ yellow lupin, $\mathrm{g} \cdot \mathrm{kg}^{-1}$} \\
\hline & & 100 & 150 & 200 & 250 \\
\hline \multicolumn{6}{|l|}{ Components, $\mathrm{g} \cdot \mathrm{kg}^{-1}$} \\
\hline wheat & 611.5 & 536.7 & 502.8 & 483.7 & 479.8 \\
\hline soyabean meal & 144.3 & 110.0 & 86.0 & 50.0 & - \\
\hline yellow lupin var. Mister & $r \quad-$ & 100.0 & 150.0 & 200.0 & 250.0 \\
\hline peas var. Trachalska & - & 100.0 & 100.0 & 100.0 & 100.0 \\
\hline rapeseed meal & 70.0 & - & - & - & - \\
\hline rapeseed oil & 51.5 & 47.0 & 55.0 & 60.0 & 63.0 \\
\hline limestone & 95.1 & 81.0 & 81.0 & 80.5 & 80.6 \\
\hline calcium phosphate & 12.8 & 12.8 & 12.9 & 13.0 & 13.1 \\
\hline $\mathrm{NaCl}$ & 1.8 & 1.9 & 2.0 & 2.0 & 1.9 \\
\hline $\mathrm{NaHCO}_{3}$ & 3.5 & 3.0 & 2.9 & 2.9 & 2.9 \\
\hline DL-Methionine & 1.5 & 1.5 & 1.5 & 2.0 & 1.5 \\
\hline L-Lysine & 1.5 & 0.2 & - & 0.1 & 0.8 \\
\hline L-Threonine & 0.5 & 0.2 & 0.2 & 0.1 & 0.4 \\
\hline L-Valine & 1.0 & 0.7 & 0.7 & 0.7 & 1.0 \\
\hline premix $0.5 \%{ }^{1}$ & 5.0 & 5.0 & 5.0 & 5.0 & 5.0 \\
\hline $\begin{array}{l}\text { Metabolizable energy, } \\
\mathrm{MJ} \cdot \mathrm{kg}^{-1}\end{array}$ & 11.61 & 11.62 & 11.68 & 11.64 & 11.62 \\
\hline \multicolumn{6}{|c|}{ Analysed nutritional value, $\mathrm{g} \cdot \mathrm{kg}^{-1}$} \\
\hline crude protein & 163.6 & 165.2 & 164.3 & 168.9 & 164.1 \\
\hline $\mathrm{Ca}$ & 35.0 & 35.3 & 35.2 & 35.0 & 35.0 \\
\hline P-available & 3.9 & 3.9 & 3.9 & 3.9 & 3.9 \\
\hline
\end{tabular}

${ }^{1}$ provided per kg diet: IU: vit. A 10000 , vit. $D_{3} 2000$; mg: vit. E 20, vit. $K_{3} 1.5$, vit. $B_{1} 1$, vit. $B_{2} 4$, vit. $B_{3} 20$, vit. $B_{5} 8$, vit. $B_{6} 1.5$, vit. $B_{9} 0.8$, choline 200, Fe 45, Mn 90, Cu 8, Zn 60, I 1, Co 0.5, Se 0.25, antioxidant 15 , biotin 50; $\mu$ g: vit. $B_{12} 3300$

- weight of yolk, thick and thin albumen and eggshell (g),

- content of yolk, thick and thin albumen and shell in the egg mass (\%),

- yolk colour (points) measured every two weeks visually using a La Roche Yolk Colour Fan (from 1 - the lightest to 15 - the darkest) (Roche, Bern, Switzerland) and with a Minolta CR-410 colorimeter (Konica Minolta, Tokyo, Japan),

- Haugh units (HU) score was calculated according to the formula:

$$
\mathrm{HU}=100 \log \left(\mathrm{h}-1.7 \mathrm{~W}^{0.37}+7.6\right)
$$

where: $\mathrm{h}$ - average thick albumen height $(\mathrm{mm})$, $\mathrm{W}$ - egg weight (g),

- $\mathrm{pH}$ of yolk and albumen using a CP-401 pH meter (Elmetron, Bydgoszcz, Poland),

- eggshell thickness (mm) together with shell membranes at the equatorial part of the egg, using a micrometre screw with $0.01 \mathrm{~mm}$ accuracy,

- eggshell strength $(\mathrm{kg})$ measured with an egg crusher (ORKA, Tel Aviv, Israel).

The methods of egg quality determination were described by Adamski (2008).

\section{Chemical analyses}

According to AOAC International (2005), nitrogen concentration (method 976.05) with the use of a Kjel Foss Automatic 16210 (A/S N. Foss Electric, Hillerod, Denmark) and crude fat (method 920.39) using a Soxtex System HT 1043 Extraction Unit (Foss Tecator, Hillerod, Denmark) were determined in the diet. To determine crude protein concentration, the assayed nitrogen was multiplied by 6.25 . Crude fibre concentrations in the diet were calculated in line with INRA standards (Sauvant et al., 2004). The concentration of carotenes and xanthophylls was analysed according to spectrophotometric method - PB 60 KLP. The amino acid (AA) content was determined by using an AAA-400 Automatic Amino Acid Analyser (Ingos, Prague, Czech Republic) with ninhydrin for post-column derivatization. Before analyses, the samples were hydrolysed with $6 \mathrm{~N} \mathrm{HCl}$ for $24 \mathrm{~h}$ at $110^{\circ} \mathrm{C}$ (procedure 994.12; AOAC International, 2005).

Lupin alkaloids were extracted from the meal with trichloroacetic acid and methylene chloride. The determination was provided by the gas chromatography method (Shimadzu GC17A, Phenomenex Inc., Torrance, CA, USA) with a capillary column (Phenomenex Inc., Torrance, CA, USA). Raffinose family oligosaccharides (RFO) in lupin seeds were extracted and analysed using high-resolution gas chromatography, as described by Zalewski et al. (2001). Phytic phosphorus was determined by extracting the sample in hydrochloric acid. Next, iron-ammonium sulphate was added to the centrifuged extract which was heated and then centrifuged. Bipyridine solution was added to the supernatant and absorbance was determined using a Media spectrophotometer (Marcel Lamidey S.A., Chatillon, France) at $519 \mathrm{~nm}$ wavelength (Hang and Lantz, 1983). The water extract viscosity (WEV) of lupin seeds was measured in vitro. Prior to the determination of WEV, lupin samples were ground in a mill to pass through a sieve with $0.5 \mathrm{~mm}$ mesh, and then $1 \mathrm{~g}$ of each of the examined cultivar was mixed with $5 \mathrm{ml}$ distilled water for $1 \mathrm{~h}$ at $40{ }^{\circ} \mathrm{C}$. The samples were centrifuged at $10000 \mathrm{~g}$ for $10 \mathrm{~min}$ at $4{ }^{\circ} \mathrm{C}$, the supernatant was withdrawn and viscosity was determined in a Brookfield Digital DV-II+ cone/plate viscometer (Brookfield Engineering Laboratories Inc., Stoughton, MA, USA) maintained at $40{ }^{\circ} \mathrm{C}$ at a shear rate of $12 \cdot \mathrm{s}^{-1}$ $\left(\mathrm{mPas} \cdot \mathrm{s}=\mathrm{cP}=1 \times 100\right.$ dyne $\cdot \mathrm{s} \cdot \mathrm{cm}^{-2}$; WEV units are $\mathrm{mPas} \cdot \mathrm{s})$. The metabolizable energy of diets was calculated based on Smulikowska and Rutkowski (2005). 


\section{Statistical analysis}

All data were examined earlier to discard any possible outliers. The analyses were performed using the appropriate procedures of SAS Software (distribution analyses; outliers were defined as observations whose distance to the location estimate exceeded 3 times the standard deviation; SAS Institute Inc., Cary, NC, USA). The obtained results were subjected to one-factorial analysis of variance (ANOVA). Experimental data were compared using the Duncan test and differences were assumed to be significant at $P<0.05$.

Regression analysis of the effects of laying period on the changes of yolk colour was performed using the following model:

$$
\mathrm{yi}=\beta_{0}+\beta_{1 \mathrm{xil}}+\varepsilon \mathrm{i}
$$

where: yi - yolk colour, $\beta_{0}, \beta_{1}$ - regression coefficients, $\mathrm{Xi}$ - laying period, $\varepsilon \mathrm{i}$ - random variable assumed to be normally distributed with mean 0 and variance $\delta^{2}$.

In the experiment, standard error of the mean (SEM) was used as a measure of error.

\section{Results}

\section{Performance}

The health status of hens was good and there was noted no mortality. Body weight of hens (Table 3) amounted on average $1.90-1.96 \mathrm{~kg}$ at the beginning and $1.63-1.66 \mathrm{~kg}$ after 22 weeks of experiment, without significant differences between treatments.

The dynamics of laying rate (Table 3 ) in the first 9 weeks of the experiment did not differ between groups. Between 10 and 18 week of egg production, there were observed differences between groups in laying rate $(P<0.05)$; only group containing $10 \%$ of yellow lupin seeds did not differ from the control group. The laying rate in group with $15 \%$ yellow lupin seed addition was lower in comparison to control group in weeks $12,15,16$ and 18 . The group with $20 \%$ yellow lupin seed addition also differed from control group but only in selected weeks: 11, 12 and 15. The laying rate in group with $25 \%$ yellow lupin seeds addition was lower than in the control group and group with $10 \%$ inclusion from 10 to 17 week and from all other treatment groups in weeks $10,11,14,15,16$ and 17. For the whole experiment the laying rate was the highest in the control group, and in groups with 10 and 20\% yellow lupin seeds addition; however groups with 10 and $20 \%$ addition also did not differ from groups fed diet with $15 \%$ addition. The lowest laying rate was obtained in birds fed diet with $25 \%$ inclusion of
Table 3. Body weight of hens and laying rate during experiment

\begin{tabular}{|c|c|c|c|c|c|c|c|}
\hline \multirow{3}{*}{$\begin{array}{l}\text { Week of } \\
\text { laying }\end{array}$} & \multicolumn{5}{|c|}{ Treatments } & \multirow{3}{*}{ SEM } & \multirow{3}{*}{$P$-value } \\
\hline & \multirow{2}{*}{ control } & \multicolumn{4}{|c|}{ yellow lupin, $\mathrm{g} \cdot \mathrm{kg}^{-1}$} & & \\
\hline & & 100 & 150 & 200 & 250 & & \\
\hline \multicolumn{8}{|c|}{ Body weight, kg } \\
\hline initial & 1.91 & 1.96 & 1.92 & 1.93 & 1.90 & 0.01 & 0.549 \\
\hline final & 1.63 & 1.63 & 1.66 & 1.65 & 1.65 & 0.01 & 0.441 \\
\hline \multicolumn{8}{|c|}{ Laying rate, $\%$} \\
\hline 1 & 74.0 & 64.8 & 64.0 & 68.4 & 70.0 & 1.66 & 0.310 \\
\hline 2 & 91.5 & 85.5 & 87.6 & 93.5 & 86.9 & 1.01 & 0.067 \\
\hline 3 & 96.5 & 96.2 & 94.3 & 96.8 & 94.6 & 0.51 & 0.411 \\
\hline 4 & 99.0 & 95.8 & 95.8 & 97.4 & 96.7 & 0.43 & 0.125 \\
\hline 5 & 97.3 & 95.6 & 94.8 & 97.0 & 95.4 & 0.52 & 0.328 \\
\hline 6 & 98.6 & 94.4 & 96.5 & 94.2 & 94.4 & 0.55 & 0.056 \\
\hline 7 & 95.4 & 95.2 & 91.9 & 93.5 & 93.2 & 0.63 & 0.341 \\
\hline 8 & 98.8 & 95.6 & 95.5 & 96.2 & 94.4 & 0.54 & 0.133 \\
\hline 9 & 97.7 & 94.6 & 94.4 & 95.8 & 92.5 & 0.63 & 0.123 \\
\hline 10 & $97.3^{\mathrm{a}}$ & $94.4^{\mathrm{a}}$ & $94.1^{\mathrm{a}}$ & $94.4^{\mathrm{a}}$ & $87.0^{\mathrm{b}}$ & 0.82 & 0.001 \\
\hline 11 & $94.8^{\mathrm{a}}$ & $90.9^{\mathrm{ab}}$ & $91.2^{\mathrm{ab}}$ & $88.0^{b}$ & $78.9^{c}$ & 1.00 & $<.0001$ \\
\hline 12 & $96.1^{\mathrm{a}}$ & $91.7^{\mathrm{ab}}$ & $89.3^{b}$ & $87.9^{b c}$ & $82.7^{\circ}$ & 1.02 & 0.001 \\
\hline 13 & $95.8^{\mathrm{a}}$ & $94.1^{\mathrm{a}}$ & $90.6^{\mathrm{ab}}$ & $90.3^{\mathrm{ab}}$ & $85.5^{b}$ & 0.90 & 0.003 \\
\hline 14 & $95.7^{\mathrm{a}}$ & $94.1^{\mathrm{a}}$ & $91.7^{\mathrm{a}}$ & $91.1^{\mathrm{a}}$ & $83.9^{b}$ & 0.87 & 0.0001 \\
\hline 15 & $95.1^{\mathrm{a}}$ & $94.4^{\mathrm{ab}}$ & $89.8^{\mathrm{b}}$ & $89.5^{\mathrm{b}}$ & $83.5^{c}$ & 0.84 & $<.0001$ \\
\hline 16 & $97.1^{\mathrm{a}}$ & $94.2^{\mathrm{ab}}$ & $92.6^{\mathrm{b}}$ & $93.7^{\mathrm{ab}}$ & $85.3^{c}$ & 0.71 & $<.0001$ \\
\hline 17 & $95.7^{\mathrm{a}}$ & $96.2^{\mathrm{a}}$ & $94.5^{\mathrm{a}}$ & $95.2^{\mathrm{a}}$ & $89.3^{b}$ & 0.66 & 0.04 \\
\hline 18 & $97.7^{\mathrm{a}}$ & $96.6^{\mathrm{ab}}$ & $93.6^{b}$ & $98.0^{\mathrm{a}}$ & $95.4^{\mathrm{ab}}$ & 0.50 & 0.026 \\
\hline 19 & 96.2 & 95.4 & 94.3 & 97.0 & 95.0 & 0.62 & 0.691 \\
\hline 20 & 96.8 & 93.5 & 93.2 & 95.4 & 91.3 & 0.64 & 0.059 \\
\hline 21 & 95.7 & 97.0 & 92.3 & 94.6 & 95.0 & 0.58 & 0.115 \\
\hline 22 & 97.1 & 97.0 & 92.1 & 96.8 & 96.5 & 0.68 & 0.094 \\
\hline Mean & $95.4^{\mathrm{a}}$ & $92.9^{\mathrm{ab}}$ & $90.8^{b c}$ & $92.6^{\mathrm{ab}}$ & $88.8^{c}$ & 0.47 & 0.0001 \\
\hline
\end{tabular}

SEM - standard error of the mean; abc - means with different superscripts within the same row are significantly different at $P \leq 0.05$

yellow lupin but this result did not differ from group with $15 \%$ yellow lupin seeds supplementation.

The egg weight varied significantly between treatments after the first 5 weeks up to 20 week of the experiment (Table 4). The mean values for the whole study show that only hens fed diet containing $25 \%$ yellow lupin seeds produced significantly smaller eggs as compared to the control and other treatments.

Feed intake during the 22 -week study varied significantly between treatments starting from week 5 of the experiment. For the whole experimental period the lowest dietary consumption was noted in the control group and in the group with $25 \%$ lupin seeds addition (Table 5); however there was observed no difference between groups with $25 \%$ and 10 or $15 \%$ addition of yellow lupin seeds.

The best FCR (Table 6) was obtained in the control hens. Inclusion of $25 \%$ yellow lupin seeds into diet negatively influenced the FCR increasing its value $(P<0.05)$. Also, the addition of 10,15 and $20 \%$ lupin seeds significantly affected FCR in comparison to control hens. 
Table 4. Egg weight during experiment, $g$

\begin{tabular}{|c|c|c|c|c|c|c|c|}
\hline \multirow{3}{*}{$\begin{array}{l}\text { Week of } \\
\text { laying }\end{array}$} & \multicolumn{5}{|c|}{ Treatments } & \multirow{3}{*}{ SEM } & \multirow{3}{*}{$P$-value } \\
\hline & \multirow{2}{*}{ control } & \multicolumn{4}{|c|}{ yellow lupin, $\mathrm{g} \cdot \mathrm{kg}^{-1}$} & & \\
\hline & & 100 & 150 & 200 & 250 & & \\
\hline 1 & 50.9 & 50.5 & 51.3 & 51.3 & 50.8 & 0.18 & 0.583 \\
\hline 2 & 52.3 & 53.5 & 53.7 & 53.7 & 52.8 & 0.23 & 0.180 \\
\hline 3 & 55.1 & 56.2 & 56.2 & 56.4 & 54.9 & 0.24 & 0.151 \\
\hline 4 & 56.8 & 57.5 & 57.7 & 57.8 & 56.3 & 0.21 & 0.097 \\
\hline 5 & 57.5 & 57.6 & 57.5 & 57.5 & 56.2 & 0.21 & 0.158 \\
\hline 6 & $57.7^{\mathrm{a}}$ & $58.2^{\mathrm{a}}$ & $57.3^{\mathrm{a}}$ & $57.4^{\mathrm{a}}$ & $55.8^{b}$ & 0.25 & 0.021 \\
\hline 7 & $58.5^{\mathrm{a}}$ & $58.3^{a}$ & $58.8^{\mathrm{a}}$ & $57.8^{\mathrm{ab}}$ & $56.6^{b}$ & 0.23 & 0.023 \\
\hline 8 & $59.1^{\mathrm{a}}$ & $59.7^{a}$ & $60.1^{\mathrm{a}}$ & $59.5^{\mathrm{a}}$ & $57.1^{\mathrm{b}}$ & 0.24 & 0.001 \\
\hline 9 & $59.7^{\mathrm{a}}$ & $60.1^{\mathrm{a}}$ & $60.5^{\mathrm{a}}$ & $59.7^{\mathrm{a}}$ & $57.5^{\mathrm{b}}$ & 0.24 & 0.001 \\
\hline 10 & $59.6^{\mathrm{a}}$ & $60.2^{\mathrm{a}}$ & $60.4^{\mathrm{a}}$ & $59.1^{a}$ & $56.5^{\mathrm{b}}$ & 0.28 & $<.0001$ \\
\hline 11 & $59.7^{\mathrm{ab}}$ & $59.9^{a}$ & $60.6^{a}$ & $58.3^{b}$ & $56.7^{c}$ & 0.27 & $<.0001$ \\
\hline 12 & $60.1^{\mathrm{a}}$ & $60.5^{\mathrm{a}}$ & $59.6^{\mathrm{a}}$ & $60.5^{\mathrm{a}}$ & $57.2^{\mathrm{b}}$ & 0.35 & 0.012 \\
\hline 13 & $59.8^{\mathrm{bc}}$ & $61.4^{\mathrm{a}}$ & $61.2^{\mathrm{ab}}$ & $59.6^{\mathrm{cd}}$ & $58.3^{d}$ & 0.25 & 0.0001 \\
\hline 14 & $60.0^{\mathrm{bc}}$ & $64.8^{a}$ & $61.0^{\mathrm{b}}$ & $60.0^{\mathrm{bc}}$ & $57.9^{c}$ & 0.41 & $<.0001$ \\
\hline 15 & $60.6^{b}$ & $65.5^{\mathrm{a}}$ & $61.5^{b}$ & $60.4^{b c}$ & $58.3^{c}$ & 0.38 & $<.0001$ \\
\hline 16 & $61.4^{\mathrm{bc}}$ & $65.7^{\mathrm{a}}$ & $62.5^{b}$ & $61.6^{b c}$ & $59.8^{c}$ & 0.33 & $<.0001$ \\
\hline 17 & $61.7^{\mathrm{bc}}$ & $63.5^{\mathrm{a}}$ & $64.0^{\mathrm{a}}$ & $62.8^{\mathrm{ab}}$ & $60.8^{c}$ & 0.27 & 0.0004 \\
\hline 18 & $62.6^{\mathrm{bc}}$ & $63.9^{\mathrm{ab}}$ & $64.7^{\mathrm{a}}$ & $63.5^{\mathrm{abc}}$ & $62.0^{\circ}$ & 0.26 & 0.008 \\
\hline 19 & $62.8^{b c}$ & $64.5^{\mathrm{ab}}$ & $65.1^{\mathrm{a}}$ & $63.2^{\mathrm{bc}}$ & $62.6^{c}$ & 0.26 & 0.006 \\
\hline 20 & $63.0^{\mathrm{ab}}$ & $63.6^{\mathrm{ab}}$ & $64.6^{\mathrm{a}}$ & $63.2^{\mathrm{ab}}$ & $61.7^{\mathrm{b}}$ & 0.29 & 0.029 \\
\hline 21 & 63.1 & 64.2 & 64.4 & 64.1 & 62.8 & 0.26 & 0.169 \\
\hline 22 & 63.0 & 64.3 & 64.8 & 64.2 & 63.3 & 0.29 & 0.228 \\
\hline Mean & $59.3^{a}$ & $60.5^{\mathrm{a}}$ & $60.4^{\mathrm{a}}$ & $59.6^{\mathrm{a}}$ & $58.0^{\mathrm{b}}$ & 0.19 & 0.0001 \\
\hline
\end{tabular}

SEM - standard error of the mean; abc - means with different superscripts within the same row are significantly different at $P \leq 0.05$

Table 6. Feed conversion ratio during experiment, $\mathrm{kg} \cdot \mathrm{kg}^{-1}$ eggs

\begin{tabular}{|c|c|c|c|c|c|c|c|}
\hline \multirow{3}{*}{$\begin{array}{l}\text { Week of } \\
\text { laying }\end{array}$} & \multicolumn{5}{|c|}{ Treatments } & \multirow{3}{*}{ SEM } & \multirow{3}{*}{$P$-value } \\
\hline & \multirow{2}{*}{ control } & \multicolumn{4}{|c|}{ yellow lupin, $\mathrm{g} \cdot \mathrm{kg}^{-1}$} & & \\
\hline & & 100 & 150 & 200 & 250 & & \\
\hline 2 & 2.18 & 2.35 & 2.27 & 2.17 & 2.34 & 0.03 & 0.202 \\
\hline 3 & 2.00 & 2.06 & 2.08 & 1.95 & 2.06 & 0.02 & 0.064 \\
\hline 4 & 1.89 & 1.96 & 1.92 & 1.89 & 1.98 & 0.01 & 0.231 \\
\hline 5 & 1.86 & 1.92 & 1.89 & 1.84 & 1.81 & 0.02 & 0.160 \\
\hline 6 & 1.87 & 2.00 & 2.04 & 1.96 & 1.95 & 0.02 & 0.091 \\
\hline 7 & 1.97 & 2.00 & 2.07 & 2.09 & 2.03 & 0.02 & 0.229 \\
\hline 8 & $1.73^{c}$ & $1.91^{b}$ & $1.87^{b}$ & $1.88^{b}$ & $2.06^{a}$ & 0.02 & $<.0001$ \\
\hline 9 & 1.88 & 1.95 & 1.95 & 1.90 & 1.97 & 0.02 & 0.259 \\
\hline 10 & $1.97^{\mathrm{b}}$ & $2.14^{a}$ & $2.05^{\mathrm{ab}}$ & $1.98^{b}$ & $2.07^{\mathrm{ab}}$ & 0.02 & 0.027 \\
\hline 11 & 1.84 & 1.93 & 1.92 & 1.97 & 2.08 & 0.03 & 0.062 \\
\hline 12 & $1.96^{c}$ & $2.11^{\mathrm{bc}}$ & $2.21^{\mathrm{ab}}$ & $2.13^{b}$ & $2.35^{\mathrm{a}}$ & 0.03 & $<.0001$ \\
\hline 13 & $1.85^{\mathrm{b}}$ & $1.95^{\mathrm{ab}}$ & $1.98^{\mathrm{a}}$ & $1.97^{\mathrm{a}}$ & $2.05^{\mathrm{a}}$ & 0.02 & 0.015 \\
\hline 14 & $1.92^{b}$ & $1.98^{b}$ & $2.03^{b}$ & $2.03^{b}$ & $2.18^{a}$ & 0.02 & 0.003 \\
\hline 15 & $1.95^{c}$ & $2.06^{b c}$ & $2.19^{a b}$ & $2.17^{\mathrm{ab}}$ & $2.31^{\mathrm{a}}$ & 0.03 & $<.0001$ \\
\hline 16 & $1.96^{c}$ & $2.05^{\mathrm{bc}}$ & $2.05^{\mathrm{bc}}$ & $2.09^{b}$ & $2.27^{\mathrm{a}}$ & 0.02 & $<.0001$ \\
\hline 17 & $1.99^{b}$ & $2.01^{b}$ & $2.06^{b}$ & $2.10^{b}$ & $2.35^{\mathrm{a}}$ & 0.02 & $<.0001$ \\
\hline 18 & $1.90^{c}$ & $1.96^{b c}$ & $2.05^{b}$ & $2.00^{\mathrm{b}}$ & $2.17^{\mathrm{a}}$ & 0.02 & $<.0001$ \\
\hline 19 & 1.88 & 1.86 & 1.95 & 1.88 & 2.02 & 0.02 & 0.072 \\
\hline 20 & $2.01^{\mathrm{c}}$ & $2.17^{\mathrm{b}}$ & $2.17^{b}$ & $2.15^{b}$ & $2.30^{a}$ & 0.02 & $<.0001$ \\
\hline 21 & $1.84^{b}$ & $1.87^{a b}$ & $1.97^{\mathrm{a}}$ & $1.91^{\mathrm{ab}}$ & $1.99^{a}$ & 0.02 & 0.037 \\
\hline 22 & $2.27^{b}$ & $2.37^{\mathrm{ab}}$ & $2.42^{\mathrm{a}}$ & $2.34^{\mathrm{ab}}$ & $2.46^{a}$ & 0.02 & 0.022 \\
\hline Mean & $1.94^{c}$ & $2.03^{b}$ & $2.06^{b}$ & $2.02^{b}$ & $2.14^{a}$ & 0.01 & $<.0001$ \\
\hline
\end{tabular}

SEM - standard error of the mean; abc - means with different superscripts within the same row are significantly different at $P \leq 0.05$
Table 5. Feed intake during experiment, $g \cdot d^{-1} \cdot$ hen $^{-1}$

\begin{tabular}{|c|c|c|c|c|c|c|c|}
\hline \multirow{3}{*}{$\begin{array}{l}\text { Week of } \\
\text { laying }\end{array}$} & \multicolumn{5}{|c|}{ Treatments } & \multirow{3}{*}{ SEM } & \multirow{3}{*}{$P$-value } \\
\hline & \multirow{2}{*}{ control } & \multicolumn{4}{|c|}{ yellow lupin, $\mathrm{g} \cdot \mathrm{kg}^{-1}$} & & \\
\hline & & 100 & 150 & 200 & 250 & & \\
\hline 1 & 99 & 103 & 101 & 102 & 100 & 0.73 & 0.342 \\
\hline 2 & 102 & 106 & 104 & 108 & 106 & 0.83 & 0.207 \\
\hline 3 & 106 & 111 & 108 & 106 & 107 & 0.64 & 0.055 \\
\hline 4 & 105 & 107 & 106 & 106 & 106 & 0.55 & 0.830 \\
\hline 5 & $104^{a}$ & $105^{\mathrm{a}}$ & $101^{\mathrm{ab}}$ & $102^{\mathrm{a}}$ & $97^{\mathrm{b}}$ & 0.77 & 0.009 \\
\hline 6 & $106^{\mathrm{ab}}$ & $109^{a}$ & $110^{\mathrm{a}}$ & $107^{\mathrm{ab}}$ & $102^{b}$ & 0.72 & 0.006 \\
\hline 7 & $108^{b c}$ & $111^{\mathrm{ab}}$ & $113^{\mathrm{a}}$ & $112^{\mathrm{ab}}$ & $105^{c}$ & 0.69 & 0.003 \\
\hline 8 & $100^{b}$ & $108^{a}$ & $109^{a}$ & $107^{a}$ & $111^{\mathrm{a}}$ & 0.71 & $<.0001$ \\
\hline 9 & $108^{\mathrm{ab}}$ & $110^{\mathrm{a}}$ & $112^{\mathrm{a}}$ & $108^{\mathrm{ab}}$ & $104^{b}$ & 0.74 & 0.010 \\
\hline 10 & $114^{\mathrm{ab}}$ & $117^{a}$ & $115^{\mathrm{ab}}$ & $110^{b}$ & $103^{c}$ & 0.90 & $<.0001$ \\
\hline 11 & $103^{a}$ & $104^{a}$ & $106^{a}$ & $100^{a}$ & $93^{b}$ & 0.97 & 0.0002 \\
\hline 12 & $111^{\mathrm{bc}}$ & $117^{a}$ & $115^{\mathrm{ab}}$ & $112^{\mathrm{abc}}$ & $109^{c}$ & 0.84 & 0.021 \\
\hline 13 & $104^{b c}$ & $112^{\mathrm{a}}$ & $110^{\mathrm{ab}}$ & $106^{b c}$ & $101^{c}$ & 0.90 & 0.001 \\
\hline 14 & $109^{a b}$ & $114^{\mathrm{a}}$ & $112^{\mathrm{a}}$ & $110^{a}$ & $104^{b}$ & 0.82 & 0.003 \\
\hline 15 & $110^{b}$ & $120^{\mathrm{a}}$ & $117^{\mathrm{ab}}$ & $117^{\mathrm{ab}}$ & $111^{b}$ & 1.11 & 0.018 \\
\hline 16 & $113^{b}$ & $120^{a}$ & $117^{\mathrm{ab}}$ & $120^{\mathrm{a}}$ & $115^{a b}$ & 0.95 & 0.046 \\
\hline 17 & $115^{b}$ & $123^{a}$ & $121^{a}$ & $125^{\mathrm{a}}$ & $127^{\mathrm{a}}$ & 0.92 & 0.0004 \\
\hline 18 & $113^{c}$ & $121^{b}$ & $122^{b}$ & $124^{\mathrm{ab}}$ & $128^{a}$ & 0.95 & $<.0001$ \\
\hline 19 & $110^{c}$ & $114^{b c}$ & $115^{\mathrm{ab}}$ & $115^{\mathrm{ab}}$ & $119^{a}$ & 0.79 & 0.006 \\
\hline 20 & $120^{b}$ & $128^{\mathrm{a}}$ & $126^{a}$ & $128^{\mathrm{a}}$ & $129^{a}$ & 0.84 & 0.001 \\
\hline 21 & $107^{b}$ & $116^{a}$ & $114^{a}$ & $115^{\mathrm{a}}$ & $118^{a}$ & 0.87 & 0.001 \\
\hline 22 & $116^{b}$ & $126^{a}$ & $123^{a}$ & $124^{\mathrm{a}}$ & $128^{a}$ & 0.87 & $<.0001$ \\
\hline Mean & $108^{c}$ & $114^{\mathrm{a}}$ & $112^{\mathrm{ab}}$ & $112^{\mathrm{ab}}$ & $110^{\mathrm{bc}}$ & 0.49 & 0.004 \\
\hline
\end{tabular}

SEM - standard error of the mean; abc - means with different superscripts within the same row are significantly different at $P \leq 0.05$

\section{Egg quality}

The inclusion of yellow lupin seeds into laying hen diet had no significant effect on egg quality parameters such as: shape index, percentage share of yolk and thick albumen content (Table 7). Significant differences between treatments for percentage share of thin albumen content were noted between the control group and group with $15 \%$ yellow lupin seeds addition. In comparison to the control group, the egg shell content decreased in all lupin treatments $(P<0.05)$.

Parallel to the rise in lupin seeds content in the diets, the $\mathrm{pH}$ value of egg content and HU units were increasing. The egg yolk colour was improved from 2.01 points in the control group to 4.61 points of the La Roche fan scale in the group fed diet containing $25 \%$ yellow lupin seeds $(P<0.01)$, also when the colour was measured with a Minolta device the same tendency was stated (Table 8; Figures 1 and $2)$. In contrast, the egg shell thickness and strength decreased significantly with the increasing lupin seeds content in the diets (Table 8). Significantly better shell quality was found in eggs from control hens, and from those receiving $10 \%$ yellow lupin seeds inclusion, the worst - by application of $25 \%$ yellow lupin seeds. 
Table 7. Morphology and physical traits of eggs

\begin{tabular}{|c|c|c|c|c|c|c|c|}
\hline \multirow{3}{*}{ Indices } & \multicolumn{5}{|c|}{ Treatments } & \multirow{3}{*}{ SEM } & \multirow{3}{*}{$P$-value } \\
\hline & \multicolumn{5}{|c|}{ yellow lupin, $\mathrm{g} \cdot \mathrm{kg}^{-1}$} & & \\
\hline & & 100 & 150 & 200 & 250 & & \\
\hline Egg shape & 72.9 & 72.5 & 72.8 & 72.8 & 73.1 & 0.07 & 0.079 \\
\hline \multicolumn{8}{|l|}{ Weight, g } \\
\hline yolk & $14.2^{\mathrm{ab}}$ & $14.2^{\mathrm{ab}}$ & $14.3^{\mathrm{a}}$ & $14.0^{\mathrm{bc}}$ & $13.9^{c}$ & 0.06 & 0.004 \\
\hline thick albumen & $21.9^{a}$ & $22.3^{\mathrm{a}}$ & $22.3^{\mathrm{a}}$ & $22.2^{\mathrm{a}}$ & $21.4^{b}$ & 0.09 & 0.002 \\
\hline thin albumen & $18.2^{\mathrm{bc}}$ & $18.0^{\mathrm{bc}}$ & $19.1^{\mathrm{a}}$ & $18.4^{\mathrm{b}}$ & $17.8^{c}$ & 0.09 & $<.0001$ \\
\hline eggshell & $6.0^{\mathrm{a}}$ & $5.8^{\mathrm{b}}$ & $5.9^{b}$ & $5.8^{\mathrm{b}}$ & $5.6^{c}$ & 0.02 & $<.0001$ \\
\hline \multicolumn{8}{|c|}{ Content, \% of egg weight } \\
\hline yolk & 23.5 & 23.6 & 23.2 & 23.2 & 23.6 & 0.07 & 0.051 \\
\hline thick albumen & 36.3 & 36.8 & 36.2 & 36.7 & 36.5 & 0.11 & 0.249 \\
\hline thin albumen & $30.2^{b}$ & $29.9^{b}$ & $31.0^{\mathrm{a}}$ & $30.5^{\mathrm{ab}}$ & $30.3^{\mathrm{ab}}$ & 0.12 & 0.028 \\
\hline eggshell & $9.9^{\mathrm{a}}$ & $9.6^{b}$ & $9.5^{b}$ & $9.6^{\mathrm{b}}$ & $9.5^{b}$ & 0.03 & $<.0001$ \\
\hline
\end{tabular}

SEM - standard error of the mean; abc - means with different superscripts within the same row are significantly different at $P \leq 0.05$
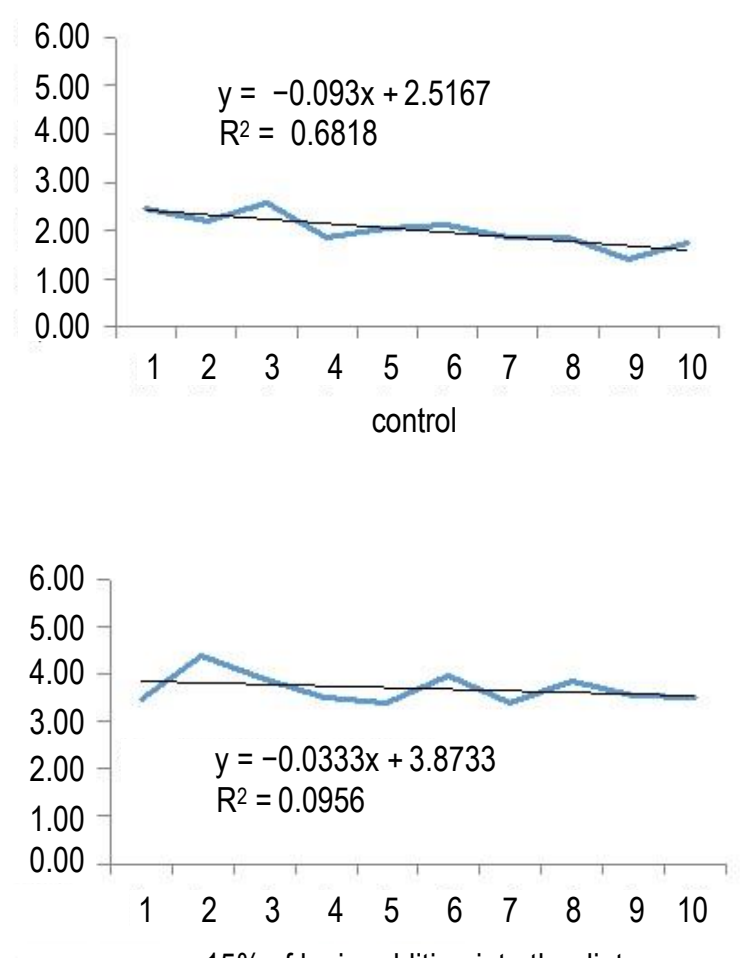

$15 \%$ of lupin addition into the diet

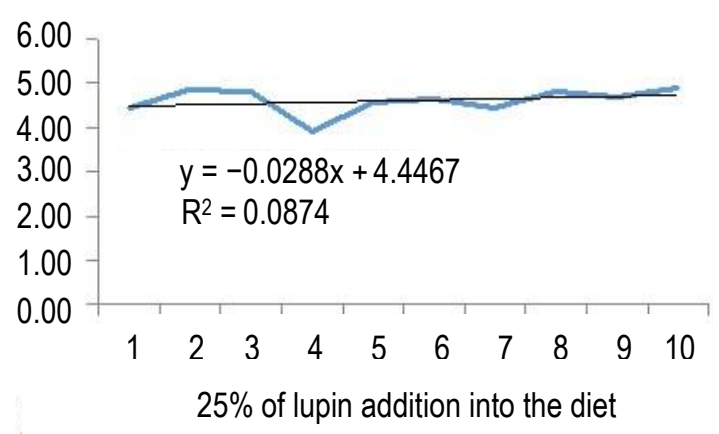

Table 8. Egg quality characteristics

\begin{tabular}{|c|c|c|c|c|c|c|c|}
\hline \multirow{3}{*}{ Indices } & \multicolumn{5}{|c|}{ Treatments } & \multirow{3}{*}{\multicolumn{2}{|c|}{ SEM $P$-value }} \\
\hline & \multicolumn{5}{|c|}{ yellow lupin, $\mathrm{g} \cdot \mathrm{kg}^{-1}$} & & \\
\hline & & 100 & 150 & 200 & 250 & & \\
\hline \multicolumn{8}{|l|}{ pH } \\
\hline yolk & $5.59^{d}$ & $5.65^{c}$ & $5.69^{b}$ & $5.74^{a}$ & $5.73^{\mathrm{a}}$ & 0.01 & $<.0001$ \\
\hline albumen & $8.01^{\mathrm{c}}$ & $8.09^{\mathrm{ab}}$ & $8.07^{b}$ & $8.12^{\mathrm{a}}$ & $8.11^{\mathrm{a}}$ & 0.01 & $<.0001$ \\
\hline $\mathrm{HU}$ & $94.17^{b}$ & $93.22^{b}$ & $95.36^{a}$ & $95.52^{\mathrm{a}}$ & $96.43^{a}$ & 0.20 & $<.0001$ \\
\hline Yolk colour $^{1}$ & $2.01^{\mathrm{e}}$ & $2.97^{d}$ & $3.69^{c}$ & $4.15^{b}$ & $4.61^{\mathrm{a}}$ & 0.01 & $<.0001$ \\
\hline$L^{*}$ & $78.89^{\mathrm{a}}$ & $77.46^{b}$ & $77.53^{b}$ & $76.56^{c}$ & $75.84^{d}$ & 0.16 & $<.0001$ \\
\hline$a^{*}$ & $-3.211^{e}$ & $-1.77^{d}$ & $-0.84^{c}$ & $-0.23^{b}$ & $0.38^{a}$ & 0.01 & $<.0001$ \\
\hline$b^{*}$ & $51.42^{\mathrm{d}}$ & $54.68^{c}$ & $56.99^{b}$ & $58.18^{\mathrm{a}}$ & $58.23^{a}$ & 0.12 & $<.0001$ \\
\hline \multicolumn{8}{|l|}{ Eggshell } \\
\hline thickness, $\mathrm{mm}$ & $0.38^{a}$ & $0.37^{b}$ & $0.37^{b}$ & $0.37^{b}$ & $0.36^{c}$ & 0.001 & $<.0001$ \\
\hline strength, kg & $4.27^{\mathrm{a}}$ & $4.03^{a}$ & $3.92^{\mathrm{bc}}$ & $3.95^{\mathrm{bc}}$ & $3.83^{c}$ & 0.03 & $<.0001$ \\
\hline
\end{tabular}

${ }^{1}$ La Roche points; SEM - standard error of the mean; HU - Haugh unit; abc - means with different superscripts within the same row are significantly different at $P \leq 0.05$
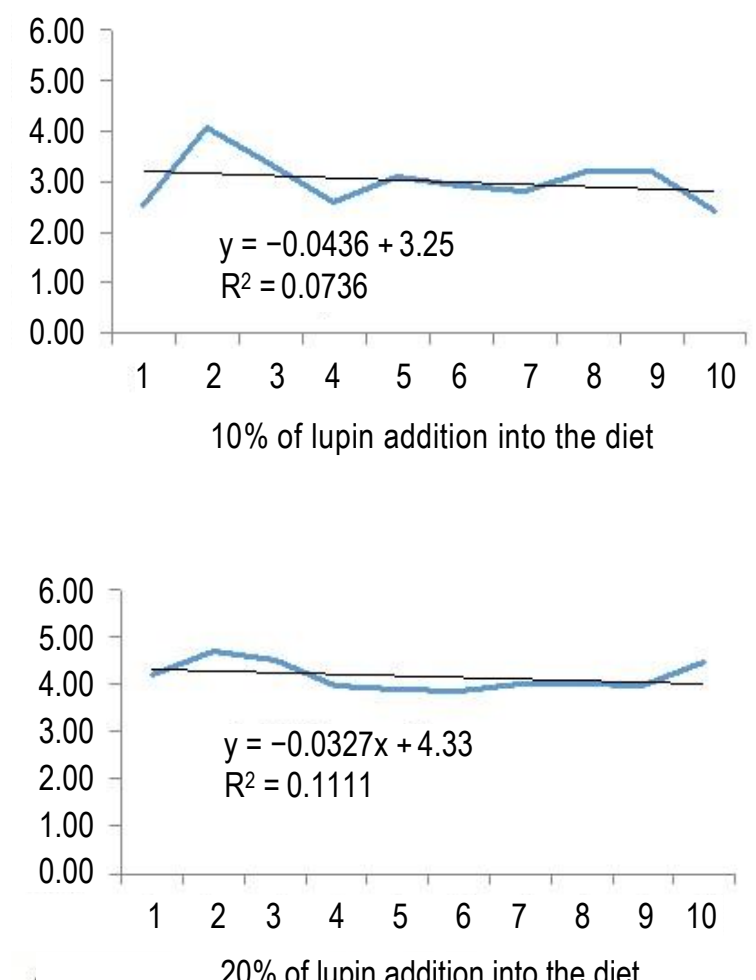

$20 \%$ of lupin addition into the diet

Figure 1. Changes of yolk colour during laying period (La Roche points) measured every two weeks of laying (from $2^{\text {nd }}$ to $20^{\text {th }}$ week of experiment) 

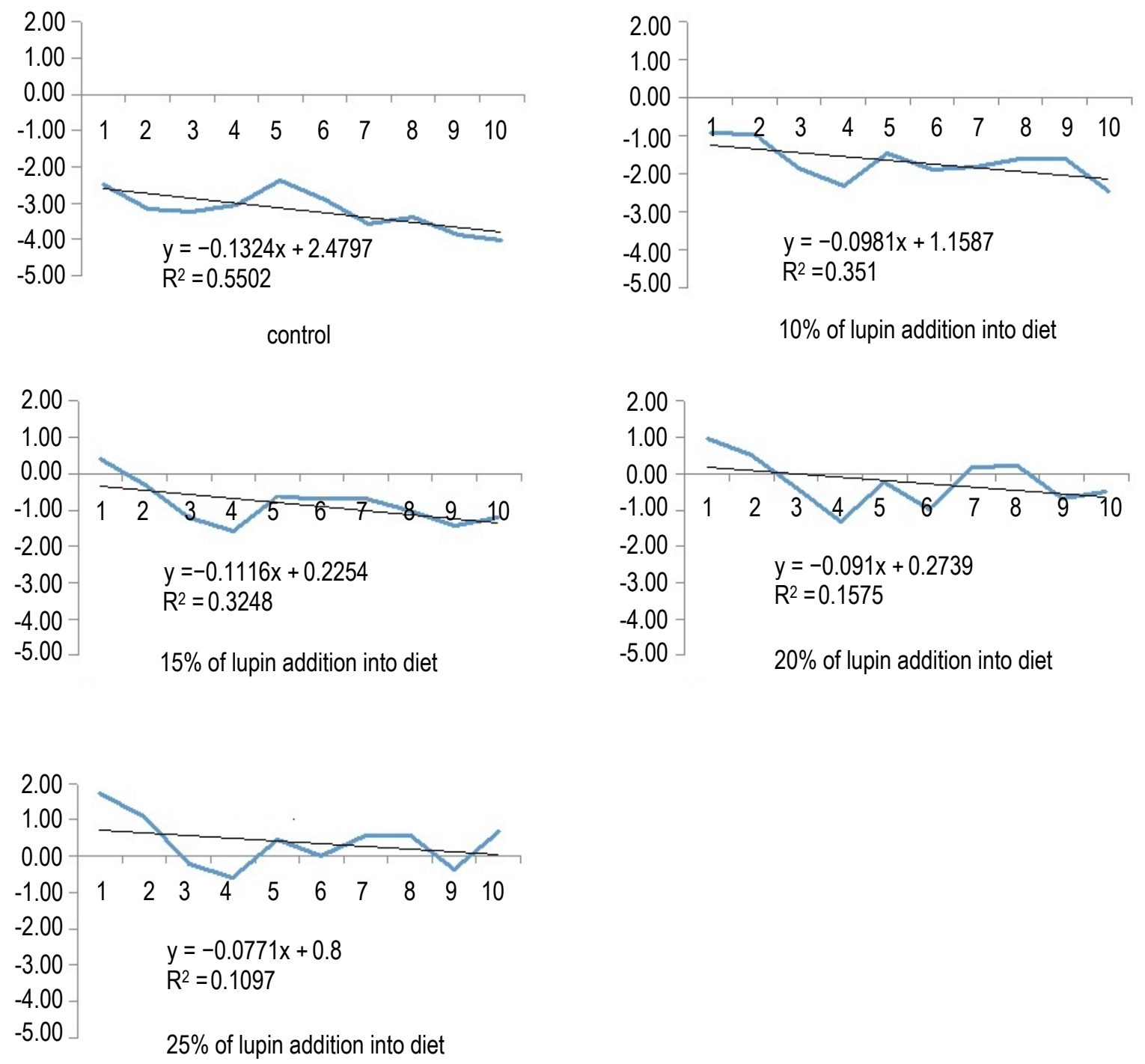

Figure 2. Changes of yolk colour during laying period ( $\left.L A B-a^{*}\right)$ measured every two weeks of laying (from $2^{\text {nd }}$ to $20^{\text {th }}$ week of experiment)

The dynamics of changes of yolk pigmentation were measured ten times every two weeks (the first time after two weeks of feeding with experimental diets), and significant differences were visible between treatments (Figures 1 and 2). In the control group, a significant aggravation of yolk pigmentation was observed. In eggs from hens fed diets with 15 , $20,25 \%$ of yellow lupin seeds the yolk colouring was relatively stable at the level of \pm 4.0 points on the La Roche scale.

\section{Discussion}

The yellow lupin seeds (var. Mister) used in this study were of good quality, with a low content of alkaloids and saccharides from the raffinose family in comparison to data presented by Gdala and $\mathrm{Bu}-$ raczewska (1996) and Wasilewko and Buraczewska
(1999). Moreover, the amino acid and phosphorus contents show that Mister seeds are a profitable component of laying hen diets. Chemical composition results obtained in this study were better than those presented by Sandberg (2002).

In comparison to many publications presenting the results of the use of yellow lupin, pea, faba beans in animal nutrition (e.g., Olkowski et al., 2005; Olkowski, 2011; Kocher et al., 2000; Kaczmarek et al., 2014, 2015; Hejdysz et al., 2015, 2016; Rutkowski et al., 2016), studies concerning the inclusion of lupin seeds into laying hen diets are not so common (Watkins and Mirosh, 1987; Hughes and Kocher, 1998; Mierlita, 2013; Krawczyk et al., 2015; Rutkowski et al., 2016). The inclusion of $25 \%$ yellow lupin seeds into diet caused a decrease in the laying rate of hens as compared to the effects of control diet and treatments with 10 and $20 \%$ lupin addition. 
The negative influence of lupin addition to hen diet was recorded by Rutkowski et al. (2015) - the 11\% yellow lupin seed inclusion evoked decreased egg production. This effect was observed after 8 weeks of feeding. In our study similar effect was observed at week 10 of the experiment. In contrast, Krawczyk et al. (2015) did not confirm the negative effect of $30 \%$ yellow lupin seeds inclusion on laying performance, feed intake, FCR and egg weight. In this study, the feed intake amounted on average $126 \mathrm{~g} \cdot \mathrm{d}^{-1} \cdot \mathrm{hen}^{-1}$ and FCR $-2.03 \mathrm{~kg} \cdot \mathrm{kg}^{-1}$ of egg weight. In our experiment, these indices were lower and amounted on average to $111 \mathrm{~g} \cdot \mathrm{d}^{-1} \cdot \mathrm{hen}^{-1}$ and FCR $-2.06 \mathrm{~kg} \cdot \mathrm{kg}^{-1} \mathrm{egg}$, respectively; hens consumed more feed with lower content of seeds or without seeds. Using 15\% Lupinus angustifolium L. in laying hen diets, Hammershoj and Steenfeldt (2005) did not observe any negative effects; however, with $25 \%$ lupin addition reduced egg production was recorded. Hughes and Kocher (1998) fed hens diets with $7.5,15$ or $22.5 \%$ narrow-leafed lupin seeds and at the end of the feeding period no negative effects were found. However, the increased lupin amounts in hen feed negatively influenced egg production indices (Mierlita, 2013); following $80 \%$ isoprotein substitution of diet components with lupin an enormous decrease in these parameters was noted. In our study only $25 \%$ inclusion of lupin into the diet led to a significant decrease in egg weight in comparison to the remaining treatments. In earlier investigations (Rutkowski et al., 2015), similar effect was presented. Krawczyk et al. (2015) recorded no differences in egg weight, shell thickness or strength after inclusion of $10-30 \%$ yellow lupin into laying hen diets.

In the study of Rutkowski et al. (2015), the use of increased amounts of yellow lupin seeds in hen diets decreased the egg quality parameters. Not only higher values of egg content $\mathrm{pH}$ and of $\mathrm{HU}$ units were determined, but also there was a decrease in the thickness, strength and share of egg shell in the egg weight. Dvořák et al. (2007) observed improved egg quality parameters after adding lupin to hen feed. Watkins and Mirosh (1987) confirmed the lack of significant differences in the HU units of eggs among treatments of hens fed diets containing 10, $15,20,25$ and $30 \%$ white lupin seeds, but $30 \%$ share of this feed component in the diet led to a decrease in egg production. Increased feed intake was found in animals fed diet with $15 \%$ lupin seeds inclusion.

In comparison to the study of Calik (2013) on the quality of eggs from Yellowleg partridge laying hens, eggs from Hy-Line Brown hens used in our study were characterized by higher HU units but lower values of albumen and yolk $\mathrm{pH}$. The increase in HU units resulting from increasing content of lupin in the diets is connected with better elasticity of thick albumen, stronger bond of ovomucins with lysozyme and better technological properties of egg albumen (Wells, 1968). Wells (1968) and Williams (1992), however, presented the view that hen nutrition does not appear to have a significant effect on albumen characteristics. Nevertheless, in our study, the presence of yellow lupin seeds in laying hen diets improved some egg quality parameters. Sikder et al. (1998) and Dvoŕák et al. (2007), and also many other authors, have underlined the fact that dietary composition significantly influences yolk colour - an important egg quality index for consumers. In our experiment, significant improvement of yolk colour (La Roche scale) was obtained as an effect of the rise in yellow lupin seeds content in the diets and increased levels from 1.59 (in group with $10 \%$ yellow lupin seeds addition) to 3.97 (in group with $25 \%$ yellow lupin seeds addition) in $1 \mathrm{~kg}$ of feed mixture. These differences between 'lupin' treatments, calculated as percentages of the La Roche points rise amounted from 49 to $249 \%$. Yellowness of yolk increased together with increasing yellow lupin seeds level in diets. More yellow yolks were noted in eggs from hens fed diets with 15, 20 and $25 \%$ yellow lupine seeds inclusion than in the remaining groups. It is possible, that inclusion of yellow lupin seeds into very poor in carotenoids wheat-pea diets, enriched the feed mixtures in those ingredients from 48.84 , 206 to $229 \%$ in comparison to the control group (except for yolk pigmentation).

\section{Conclusions}

The use of up to $20 \%$ of yellow lupin seeds in diet instead of soyabean meal did not decrease laying rate and egg weight. However, the egg quality was decreased in line with the increasing yellow lupin seeds content in the diets (except for yolk pigmentation).

\section{Acknowledgements}

This project was supported by the founds from the programme 'Improvement of native plant protein feeds, their production, trade turnover, and utilisation in animal feed' initiated by the Ministry of Agriculture and Rural Development of Poland, No. 50503707. 


\section{References}

Adamski M., 2008. Relationships between the morphological composition of eggs and the hatchability of chicks of selected bird species (in Polish). Zesz. Nauk. (Rozprawy) Zootech. Wydawnictwa Uczelniane Uniwersytetu TechnologicznoPrzyrodniczego. Bydgoszcz (PL), pp. 1-102

AOAC International, 2005. Official Methods of Analysis of the AOAC International. 18 $8^{\text {th }}$ Edition. Gaithersburg, MD (USA)

Calik J., 2013. Changes in quality traits of eggs from Yellowleg partridge (Ż-33) laying hens depending on storage conditions of eggs (in Polish). Zywn.-Nauka Technol. Jakosc 2, 87, 73-79

Dvořák P., Straková E., Kunová J., Kunová V., 2007. Egg yolk colour depends upon the composition of the feeding mixture for laying hens. Acta Vet. Brno 76, 121-127, https://doi.org/10.2754/ avb200776010121

Gdala J., 1998. Composition, properties and nutritive value of dietary fibre of legume seeds. A review. J. Anim. Feed Sci. 7, 131-150, https://doi.org/10.22358/jafs/69204/1998

Gdala J., Buraczewska L., 1996. Chemical composition and carbohydrate content of seeds from several lupin species. J. Anim. Feed Sci. 5, 403-416, https://doi.org/10.22358/jafs/69618/1996

Hammershoj M., Steenfeldt S., 2005. Effect of blue lupin (Lupinus angustifolius) in organic layer diets and supplementation with foraging material on egg production and some egg quality parameters. Poultry Sci. 84, 723-733, https://doi.org/10.1093/ ps/84.5.723

Hang W., Lantz H.-J., 1983. Sensitive method for the rapid determination of phytate in cereals and cereal products. J. Sci. Food Agric. 34, 1423-1426, https://doi.org/10.1002/jsfa.2740341217

Hejdysz M., Kaczmarek S.A., Rutkowski A., 2015. Factors affecting the nutritional value of pea (Pisum sativum) for broilers. J. Anim. Feed Sci. 24, 252-259, https://doi.org/10.22358/ jafs/65631/2015

Hejdysz M., Kaczmarek S.A., Adamski M., Rutkowski A., 2017. Influence of graded inclusion of raw and extruded pea (Pisum sativum L.) meal on the performance and nutrient digestibility of broiler chickens. Anim. Feed Sci. Techol. 230, 114-125, https:// doi.org/10.1016/j.anifeedsci.2017.05.016

Hejdysz M., Kaczmarek S.A., Rutkowski A., 2016. Extrusion cooking improves the metabolisable energy of faba beans and the amino acid digestibility in broilers. Anim. Feed Sci. Technol. 212, 100-111, https://doi.org/10.1016/j.anifeedsci.2015.12.008

Hughes R.J., Kocher A., 1998. Nutritive value of lupins for layers. Proc. Aust. Poult. Sci. Sym. 1998, Article No. 10, 140-143

Jamroz D., Kubizna J., 2008. Harmful substances in legume seeds their negative and beneficial properties. Pol. J. Vet. Sci. 11, 389-404

Kaczmarek S.A., Cowieson A.J., Hejdysz M., Rutkowski A., 2015. Microbial phytase improves performance and bone traits in broilers fed diets based on soybean meal and containing lupin meal. Anim. Prod. Sci. 56, 1669-1676, https://doi.org/10.1071/ AN14856

Kaczmarek S.A., Kasprowicz-Potocka M., Hejdysz M., Mikuła R., Rutkowski A., 2014. The nutritional value of narrow-leafed lupin (Lupinus angustifolius) for broilers. J. Anim. Feed Sci. 23, 160-166, https://doi.org/10.22358/jafs/65705/2014

Kasprowicz-Potocka M., Zaworska A., Kaczmarek S.A., Rutkowski A., 2016. The nutritional value of narrow-leafed lupine (Lupinus angustifolius) for fattening pigs. Arch. Anim. Nutr. 70, 209-223, https://doi.org/10.1080/1745039X.2016.1150238

Knudsen K.E.B., 1997. Carbohydrate and lignin contents of plant materials used in animal feeding. Anim. Feed Sci. Techol. 67, 319-338, https://doi.org/10.1016/S0377-8401(97)00009-6
Knudsen K.E.B., 2014. Fiber and nonstarch polysaccharide content and variation in common crops used in broiler diets. Poult. Sci. 93, 2380-2393, https://doi.org/10.3382/ps.2014-03902

Kocher A., Choct M., Hughes R.J., Broz J., 2000. Effect of food enzymes on utilisation of lupin carbohydrates by broilers. Br. Poult. Sci. 41, 75-82, https://doi.org/10.1080/00071660086448

Krawczyk M., Przywitowski M., Mikulski D., 2015. Effect of yellow lupine (L. luteus) on the egg yolk fatty acid profile, the physicochemical and sensory properties of eggs and laying hen performance. Poult. Sci. 94, 1360-1367, https://doi.org/10.3382/ ps/pev092

Laudadio V., Tufarelli V., 2011a. Dehulled micronised lupin (Lupinus albus L. cv. Multitalia) as the main protein source for broilers: influence on growth performance, carcass traits and meat fatty acid composition. J. Sci. Food Agric. 91, 2081-2087, https://doi.org/10.1002/jsfa.4426

Laudadio V., Tufarelli V., 2011b. Influence of substituting dietary soybean meal for dehulled-micronized lupin (Lupinus albus cv. Multitalia) on early phase laying hens production and egg quality. Livest. Sci. 140, 184-188, https://doi.org/10.1016/j. livsci.2011.03.029

Mierlita D., 2013. Effect of partial substitution of soybean meal with lupine seeds in feeding laying hens on production and economic performance. Bull. UASVM Anim. Sci. Biotechnol. 70, 37-44, http://dx.doi.org/10.15835/buasvmcn-asb:70:1:9290

Olkowski B., 2011. Lupin as primary protein source in young broiler chicken diets: Effect of enzymes preparations catalysing degradation of non-starch polysaccharides or phytates. World J. Microbiol. Biotechnol. 27, 341-347, https://doi.org/10.1007/ s11274-010-0464-x

Olkowski B.I., Classen H.L., Wojnarowicz C., Olkowski A.A., 2005. Feeding high levels of lupine seeds to broiler chickens: plasma micronutrient status in the context of digesta viscosity and morphometric and ultrastructural changes in the gastrointestinal tract. Poult. Sci. 84, 1707-1715, https://doi.org/10.1093/ ps/84.11.1707

Rutkowski A., Kaczmarek S.A., Hejdysz M., Jamroz D., 2016. Effect of extrusion on nutrients digestibility, metabolizable energy and nutritional value of yellow lupine seeds for broiler chickens. Ann. Anim. Sci. 16, 1059-1072, https://doi.org/10.1515/aoas2016-0025

Rutkowski A., Kaczmarek S.A., Hejdysz M., Nowaczewski S., Jamroz D., 2015. Concentrates made from legume seeds (Lupinus angustifolius, Lupinus luteus and Pisum sativum) and rapeseed meal as protein sources in laying hen diets. Ann. Anim. Sci. 15, 129-142, https://doi.org/10.2478/aoas-2014-0061

Sandberg A.-S., 2002. Bioavailability of minerals in legumes. Br. J. Nutr. 88, 281-285, https://doi.org/10.1079/BJN/2002718

Sauvant D., Perez J.-M., Tran G. (Editors), 2004. Tables of Composition and Nutritional Value of Feed Materials. Wageningen Academic Publishers (The Netherlands) and INRA, Paris (France)

Sikder A.C., Chowdhury S.D., Rashid M.H., Sarker A.K., Das S.C., 1998. Use of dried carrot meal (DCM) in laying hen diet for egg yolk pigmentation. Asian-Australas J. Anim. Sci. 11, 239244, https://doi.org/10.5713/ajas.1998.239

Smulikowska S., Rutkowski A. (Editors), 2005. Recommended Allowances and Nutritive Value of Feedstuffs. Poultry Feeding Standards (in Polish). $4^{\text {th }}$ Edition. The Kielanowski Institute of Animal Physiology and Nutrition, PAS, Jabłonna (Poland)

Wasilewko J., Buraczewska L., 1999. Chemical composition including content of amino acids, minerals and alkaloids in seeds of three lupin species cultivated in Poland. J. Anim. Feed Sci. 8, 1-12, https://doi.org/10.22358/jafs/68803/1999 
Watkins B.A., Mirosh L.W., 1987. White lupin as a protein source for layers. Poult. Sci. 66, 1798-1806, https://doi.org/10.3382/ ps.0661798

Wells R.G., 1968. The measurement of certain egg quality characteristics: a review. In: T.C. Carter (Editor). Egg Quality. A Study of the Hen's Egg. Oliver and Boyd, Edinbourgh (UK), pp. 207-250
Williams K.C., 1992. Some factors affecting albumen quality with particular reference to Haugh units score. Worlds Poult. Sci. J. 48, 5-16

Zalewski K., Lahuta L.B., Horbowicz M., 2001. The effect of soil drought on the composition of carbohydrates in yellow lupin seeds and triticale kernels. Acta Physiol. Plant. 23, 73-78, https://doi.org/10.1007/s11738-001-0025-x 